\title{
Shade tree species diversity and coffee productivity in Sumberjaya, West Lampung, Indonesia
}

\author{
RUSDI EVIZAL $^{1, \vartheta}$, SUGIATNO ${ }^{1}$, FEMBRIARTI ERRY PRASMATIWI ${ }^{2}$, INDAH NURMAYASARI ${ }^{2}$ \\ ${ }^{1}$ Department of Agrotechnology, Faculty of Agriculture, University of Lampung. Jl. Sumantri Brojonegoro No. 1, Bandar Lampung 35145, Lampung, \\ Indonesia. Tel.: +62721704946, Fax.: +62721770347, ‘email: rusdievizal@yahoo.com \\ ${ }^{2}$ Department of Agribusiness, Faculty of Agriculture, University of Lampung. Jl. Sumantri Brojonegoro No. 1, Bandar Lampung 35145, Lampung, \\ Indonesia
}

Manuscript received: 19 October 2015. Revision accepted: 22 March 2016.

\begin{abstract}
Evizal R, Sugiatno, Prasmatiwi FE, Nurmayasari I. 2016. Shade tree species diversity and coffee productivity in Sumberjaya, West Lampung, Indonesia. Biodiversitas 17: 234-240. Shade tree is an important variable that determines the productivity and sustainability of coffee plantation. In West Lampung, Indonesia coffee is grown on private land and on state land of Community Forest Program (CFP) using various types of shade trees. The research explored the diversity of shade trees and its influence on the productivity of coffee farms. The study area was one purposively sampled coffee farmer group in Sumberjaya District, West Lampung. We purposively chose one coffee farmer group. The group members' farms located in private land and in CFP land were sampled randomly, each consisted of 18 farms. From each farm, we observed a plot of $50 \mathrm{~m}$ x $50 \mathrm{~m}$ and interviewed the farmer who managed the farm. Data collected were on the species and the number of trees, farm age, coffee tree densities, and productivity of coffee in the last 3 years. Data analyses of important value, tree species diversity, correlation, and regression were performed. Shade trees found in coffee farms of Sumberjaya were 36 species, 10 species $(28 \%)$ of them were legume trees. Technical shade trees that have high importance value were Gliricidia sepium and Erythrina subumbrans. Multi Purpose Trees Species (MPTS) widely planted were Durio zibethinus and Parkia speciosa. The wood trees with a high importance value in the CFP coffee farms were Shorea javanica and Michelia champaca while in private coffee farms were Maesopsis eminii and Litsea sp. Based on Shannon's index (H') and Simpson's dominance index $(\lambda)$, a high diversity of shade tree species was found in CFP coffee farms at age $\geq 20$ years. Shade trees with high dominance index had a positive effect on productivity of coffee and the percentage of MPTS had a negative effect. Whereas, the types of land tenure (private or CFP) and the abundance of shade trees did not affect the productivity of coffee.
\end{abstract}

Keywords: coffee, community forest, productivity, shade tree diversity

\section{INTRODUCTION}

Lampung Province is a center of the production of Indonesian Robusta coffee which is grown mainly in the mountainous region of Bukit Barisan (Philpott et al. 2008), including on private land and on the state land of Community Forest Program (CFP). As farmers participate in CFP must plant at least 400 trees per hectare, the CFP significantly increased planting of wood trees species and Multi Purpose Trees Species (MPTS) and also increased farmers' income (Pender et al. 2008).

Cultivating coffee under varieties of shade tree species is one of local wisdoms that have long been practiced in the District of Sumberjaya, West Lampung, Indonesia (Verbist et al. 2005). Understanding the diversity, characteristics and functions of shade trees as well as its strata is important in efforts to improve the sustainability of coffee agro-ecosystem (Mamani-Pati et al. 2012), and to improve biodiversity conservation (Lopez-Gomez et al. 2008) including to conserve native tree species (Tadesse et al. 2014).

Ecological functions of the shade trees in coffee agroforestry system are as environmental services, such as recycling nutrients (Lopez-Rodriguez et al. 2015), driving soil conservation (Lin and Richards 2007), improving growth, productivity, and quality of coffee (Bote and Struik 2011), and regulating biomass production (Evizal et al. 2009) including fire wood and timber as a source of alternative income (Shalene et al. 2014) and fodder for livestock production (Geta et al. 2014). Farmers realize those functions but decisions on shade trees management are more to keep the coffee production rather than reasons of environmental services (Cerdan et al. 2012). However, study on coffee agroforestry in Sumberjaya is important to support the conservation of water supply to the electric power plant of Way Besai (Pasha et al. 2012). Management of agroforestry systems in a sustainable manner requires conservation and proper management of MPTS strata (Tscharntke et al. 2011).

Shade trees in coffee plantations can be technical shade trees, wood trees, or MPTS. Determining the composition of shade trees is important to maintain the balance of the ecological functions and the coffee agro-ecosystem productivity (Tscharntke et al. 2011). Technical shade trees are legume trees planted on coffee plantations, not to harvest the yield but to provide shade for the coffee plants. In West Lampung, technical shade trees most widely grown are Erythrina subumbrans and Gliricidia sepium (Evizal et al. 2012). 
CFP of coffee plantations in protected areas requires planting trees or MPTS that will affect the shade tree diversity and productivity of coffee plants under the shade. The research objectives were to explore the diversity of shade trees and its influence on the productivity of coffee plantations on private land and CFP land in District of Sumberjaya, West Lampung.

\section{MATERIALS AND METHODS}

\section{Field study}

We purposively chose one coffee farmer group in Sumberjaya District, West Lampung, Indonesia (Figure 1). The group members' farms located in private land and in CFP land were sampled randomly, each consisted of 18 farms. From each farm, we observed a plot of $50 \mathrm{~m}$ x $50 \mathrm{~m}$ and interviewed the farmer who managed the farm. Data collected were on the species and the number of the trees, farm age, coffee tree densities, and productivity of coffee in the last 3 years.

\section{Data analysis}

Data analyses of importance value, tree species diversity, correlation, and regression were performed. Analyses of Importance Value (IV) and diversity index are based on report of Sumantra et al. (2012). We calculated IV as sum of Relative Density and Relative Frequency and expressed diversity index based on the proportion $(\mathrm{n} / \mathrm{N})$ of individuals (n) of one particular species found (i) divided by total number of individuals found $(\mathrm{N})$. The formula of Shannon-Wiener index of species diversity $\left(H^{\prime}\right)$ is:

$$
H^{\prime}=-\sum_{i=1}^{m}\left[\frac{n i}{N}\right] \ln \left[\frac{n i}{N}\right]
$$

We calculate Simpson's dominance index $(\lambda)$ using formula (Morris et al. 2014):

$$
\lambda=\sum_{i=1}^{n}\left[\frac{\mathrm{ni}}{\mathrm{N}}\right]^{2}
$$

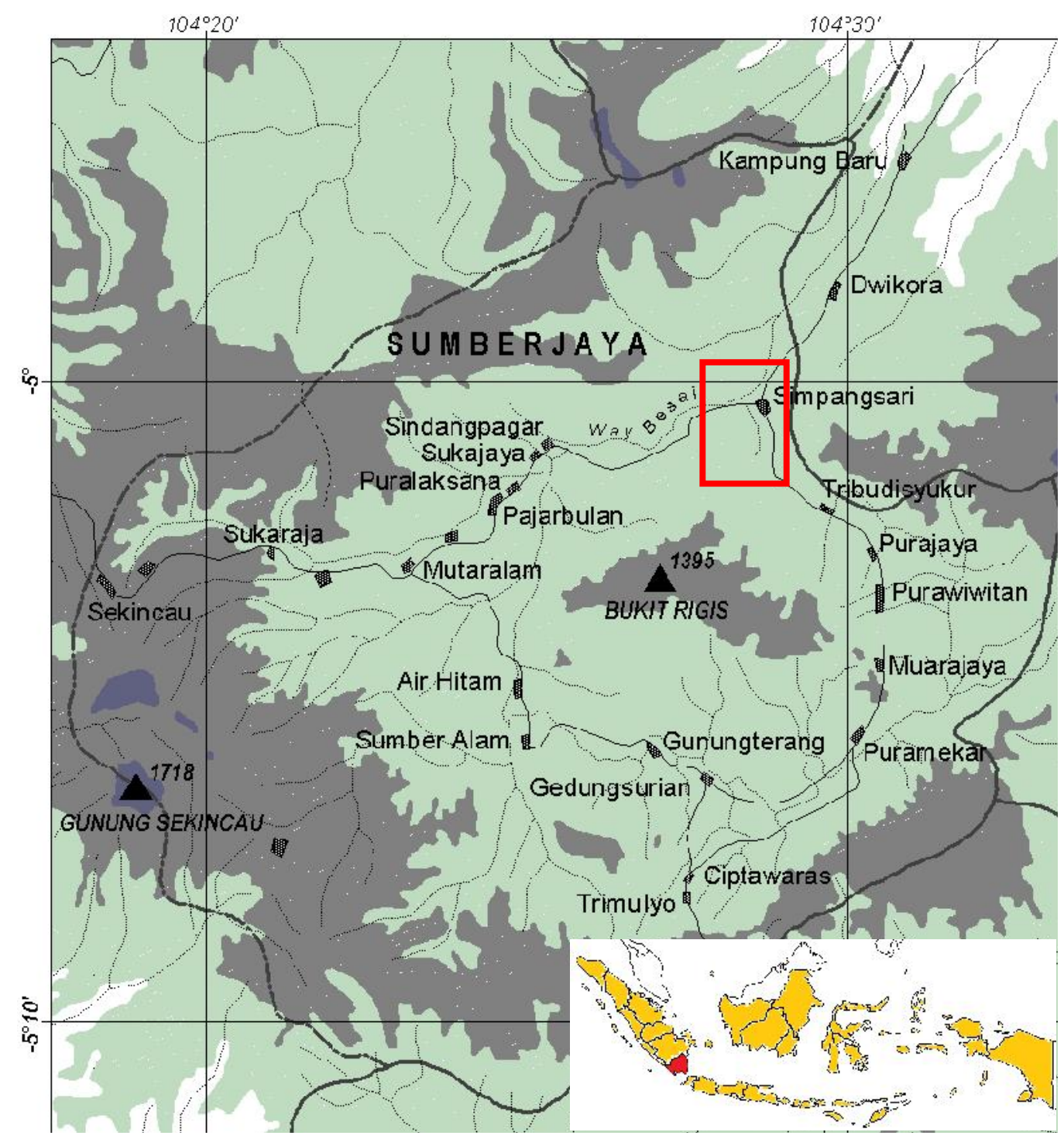

Figure 1. Study site in Sumberjaya, West Lampung, Indonesia (in red mark) (ICRAF in Pender et al. 2008) 


\section{RESULTS AND DISCUSSION}

\section{Importance value}

Shade trees found in coffee farms of Sumberjaya were 36 species, 10 species (28\%) of which were legume trees, namely G. sepium (gliricidia), E. subumbrans (coral trees), Leucaena leucocephala (lamtoro), Dalbergia latifolia (black rosewood), Paraserianthes falcataria (sengon), Parkia speciosa (petai), Swietenia mahagoni (mahogany), Acacia sp., Archidendron pauciflorum, and Archidendron microcarpum. CFP coffee farms had higher richness of shade trees with 31 species, whereas private coffee farms had 24 species. Comparing between coffee farms at age of $<20$ year and at age of $>20$ year, the density of shade trees increased from 97 to 160 trees in private coffee farms and from 276 to 350 trees in CFP coffee farms (Table 1). Technical shade trees species found in coffee farms were G. sepium, E. subumbrans, L. leucocephala, D. latifolia, and P. falcataria, but only G. sepium and E. subumbrans had high Importance Value. MPTS widely planted in coffee farms were P. speciosa, Durio zibethinus (durian), Artocarpus heterophyllus (jackfruit) and Musa paradisiaca (bananas). The wood trees with a high importance value in the CFP coffee farms were Shorea javanica and Michelia champaca while in private coffee farms were Maesopsis eminii and Litsea sp.

These results indicated that the shade trees commonly found in coffee farms in Sumberjaya were exotic species. Native tree species that had significant importance value in the CFP coffee farms were D. zibethinus, Alstonia scholaris, Shorea sp. and S. javanica. Trees of native species and exotic species were planted because it has economic value as an incentive (Ambinakudige and Sathish 2008), so that shaded coffee farms could serve as refugia for native tree species (Tadesse et al. 2014). In Sumberjaya, shade trees also functions as source of fodder from leaves of G. sepium, E. subumbrans, P. falcataria, M. eminii, Litsea sp., M. champaca, A. heterophyllus, Artocarpus champeden and Persea americana.

Tabel 1. Abundance and importance value (IV) of shade trees in private and CFP coffee farms

\begin{tabular}{|c|c|c|c|c|c|c|c|c|}
\hline \multirow{3}{*}{ Tree species } & \multicolumn{4}{|c|}{ Private $(n=18)$} & \multicolumn{4}{|c|}{ CFP $(n=18)$} \\
\hline & \multicolumn{2}{|c|}{$<20 \mathrm{y}$} & \multicolumn{2}{|c|}{$\geq 20 y$} & \multicolumn{2}{|c|}{$<20 y$} & \multicolumn{2}{|c|}{$\geq 20 y$} \\
\hline & Tree ha $^{-1}$ & IV & Tree ha $^{-1}$ & IV & Tree ha $^{-1}$ & IV & Tree ha $^{-1}$ & IV \\
\hline Gliricidia sepium & 12.50 & 19.85 & 73.73 & 64.05 & 67.78 & 32.86 & 43.75 & 17.34 \\
\hline Erythrina subumbrans & 6.67 & 13.80 & 14.54 & 21.09 & 7 & 8.78 & 9.75 & 7.62 \\
\hline Leucaena leucocephala & 1.67 & 5.17 & 0 & 0 & 0 & 0 & 0.75 & 1.83 \\
\hline Dalbergia latifolia & 0 & 0 & 0.27 & 2.17 & 0 & 0 & 7.75 & 7.05 \\
\hline Paraserianthes falcataria & 0 & 0 & 0.91 & 2.57 & 0 & 0 & 0 & 0 \\
\hline Maesopsis eminii & 12.5 & 23.30 & 6.64 & 10.15 & 0.22 & 2.164 & 1.25 & 1.97 \\
\hline Litsea $\mathrm{sp}$ & 14.5 & 21.92 & 3.45 & 6.16 & 3.33 & 3.29 & 0 & 0 \\
\hline Alstonia scholaris & 0 & 0 & 8 & 6.99 & 0.67 & 2.32 & 25.62 & 12.16 \\
\hline Swietenia mahagoni & 7.33 & 14.50 & 0 & 0 & 13 & 10.95 & 0 & 0 \\
\hline Michelia champaca & 4 & 7.59 & 0 & 0 & 54.11 & 32.08 & 45.12 & 20.96 \\
\hline Tectona grandis & 0 & 0 & 0 & 0 & 0 & 0 & 3.5 & 2.61 \\
\hline Shorea sp. & 0 & 0 & 0 & 0 & 0 & 0 & 3.125 & 2.51 \\
\hline Cananga sp. & 0 & 0 & 0 & 0 & 0 & 0 & 0.75 & 1.83 \\
\hline Toona sinensis & 8.333 & 12.08 & 0 & 0 & 0 & 0 & 0 & 0 \\
\hline Acacia sp. & 0 & 0 & 2.27 & 3.42 & 0 & 0 & 0 & 0 \\
\hline Shorea javanica & 0 & 0 & 0 & 0 & 57.78 & 27.16 & 65 & 23.42 \\
\hline Parkia speciosa & 3.333 & 6.90 & 7.73 & 12.83 & 18.44 & 19.17 & 21 & 14.07 \\
\hline Durio zibethinus & 4.17 & 11.21 & 23.82 & 28.88 & 28.89 & 20.87 & 36.87 & 21.83 \\
\hline Artocarpus heterophyllus & 2.33 & 12.76 & 6.09 & 13.8 & 4 & 7.70 & 7.12 & 10.10 \\
\hline Musa paradisiaca & 11 & 21.74 & 6.27 & 11.92 & 2.22 & 2.89 & 6.25 & 5.01 \\
\hline Persea americana & 0.33 & 7.24 & 0.73 & 4.45 & 2.78 & 5.17 & 5.75 & 8.09 \\
\hline Cinnamomum burmannii & 0.50 & 3.97 & 0 & 0 & 0 & 0 & 5 & 3.04 \\
\hline Archidendron pauciflorum & 0 & 0 & 4.54 & 4.84 & 8.22 & 13.39 & 1.87 & 3.76 \\
\hline Carica papaya & 0.67 & 4.14 & 0 & 0 & 0 & 0 & 0 & 0 \\
\hline Areca catechu & 4.667 & 8.28 & 0 & 0 & 0.89 & 2.40 & 5.12 & 4.69 \\
\hline Anacardium occidentale & 2 & 5.52 & 0 & 0 & 0 & 0 & 0 & 0 \\
\hline Artocarpus communis & 0 & 0 & 0 & 0 & 2.22 & 2.89 & 5 & 4.65 \\
\hline Aleurites moluccana & 0 & 0 & 0 & 0 & 3.11 & 5.29 & 2.5 & 2.33 \\
\hline Mangifera indica & 0 & 0 & 0.82 & 4.51 & 0 & 0 & 0.37 & 1.72 \\
\hline Artocarpus champeden & 0 & 0 & 0.27 & 2.17 & 0 & 0 & 0.63 & 1.79 \\
\hline Hevea brasiliensis & 0 & 0 & 0 & 0 & 0 & 0 & 42.5 & 13.76 \\
\hline Ceiba pentandra & 0 & 0 & 0 & 0 & 0 & 0 & 0.75 & 1.83 \\
\hline Syzygium aromaticum & 0 & 0 & 0 & 0 & 0 & 0 & 2.5 & 2.33 \\
\hline Gnetum gnemon & 0 & 0 & 0 & 0 & 0 & 0 & 0.25 & 1.68 \\
\hline Archidendron microcarpum & 0 & 0 & 0 & 0 & 1.11 & 0.40 & 0 & 0 \\
\hline Syzygium aqueum & 0 & 0 & 0 & 0 & 0.56 & 0.20 & 0 & 0 \\
\hline Total & 96.5 & 200 & 160.1 & 200 & 276.3 & 200 & 349.9 & 200 \\
\hline
\end{tabular}




\section{Tree composition}

Types of shade trees consist of technical shade trees (legumes), wood trees, and MPTS. When comparing the composition of shade tree types, in the private coffee farms at age <20 years, the dominant shade trees are MPTS, especially bananas, whereas at age $\geq 20$ years, the dominant trees are technical shade trees, especially G. sepium. This showed that in the initial opening of the coffee farms, farmers planted banana as a source of income and planted E. subumbrans as shade, then planted G. sepium trees while E. subumbrans grew old and died.

In the CFP coffee farms, the dominant shade trees are MPTS (Table 2). Cultivating coffee and MPTS in a protected area is legal under license of CFP. Farmers are allowed to harvest non-wood yield such as fruits, beverages, spices, resin, or latex to generate income. There is no incentive for farmers to plant wood trees in CFP land because farmers are not allowed to cut and harvest timber. Meanwhile, cultivating coffee and MPTS in state-owned forest of national park is illegal so that, as Phillpot et al. (2008) reported, there are more abundant MPTS in private coffee farm land than in illegal coffee farms of national park. In general, shaded coffee plantations have high number of tree species (Capitan et al. 2014) even more than in forest areas (Lopez-Gomez et al. 2008) that may have been disturbed.

The number of shade trees increases with the increasing of coffee tree age, which was shown by the ratio of shade trees to coffee tree (Table 2). Thus the carbon stocks of shaded coffee farms increases with the age of coffee and shade trees particularly in the farms at the age of 20 years and more. When the coffee trees grow larger and shade tree species increase in number and diversity, it will form a complex coffee agroforestry that shaded coffee plantations have a role in carbon sequestration (Goodall et al. 2014) and climate change mitigation (Mbow et al. 2014).

The private coffee farms of $\geq 20$ years, with $51.8 \%$ of the shade trees are technical of legume shade trees, gave the highest productivity compared to the other types of coffee farms (Table 2). This indicated that the high coffee productivity was obtained when technical shade trees, especially legume tress, were established. Legume trees that serve moderate shade level, shed the leaves in the dry season which created conditions to encourage coffee flowering, and produced much litter biomass (Evizal et al. 2009).

Meanwhile according to farmers, some species of shade trees could harm the growth and productivity of coffee trees, especially those of MPTS including Aleurites moluccana, Cinnamomum burmannii, Hevea brasiliensis, D. zibethinus and those of wood trees including M. eminii, Shorea spp., M. champaca, and Litsea sp. Some studies reported that the dominant shade tree species affect the growth and productivity of coffee (Kufa and Burkhardt 2011; Ebisa 2014). Farmers classify the effect of shade trees on the coffee plants as hot, medium, and cool. To choose shade tree species, they consider the shape of the canopy, litter production, rooting properties (Cerdan et al. 2012), nitrogen fixation, and the harvest of fruit or wood.
Preferred tree species will dominate the composition of coffee shade trees (Valencia et al. 2015).

At the private land, higher Shannon diversity index of shade tree species was found in coffee farms at age of $<20$ years, while at the CFP land, higher Shannon diversity index was found in coffee farms at age of $\geq 20$ years (Table 3 ). However, the diversity indexes were still classified as a medium diversity. The diversity index of shade trees found in private coffee farms at age of $\geq 20$ years was $<1$ and categorized as low diversity (Maridi et al. 2014). Related to Simpson's dominance index $(\lambda)$ and species richness, in the private coffee farms, the older the coffee farms the lower the diversity index of shade trees. On the contrary, in CFP land, the older the coffee farms the higher the diversity index of shade trees. These results indicated that the composition of shade tree was dynamic according to the knowledge and local wisdom of farmers to sustain productivity of coffee farm (Soto-Pinto et al. 2007). Sustainable coffee plantations are not only determined by the high diversity of flora and fauna as ecological indicators (Moonen and Barberi 2008), but also by the coffee productivity as an economic indicator. As further analysis, the relationship between the diversity index of shade trees and coffee productivity was approximated by correlation and regression analysis as shown at Tables 4 and 5.

\section{Coffee productivity}

There was a negative correlation $(r=-0.57)$ between the shade tree diversity (Shannon's index) and the coffee production in CFP land. This meant that a high diversity of shade tree species could lead to lower coffee productivity. The same meaning was indicated by positive correlation of dominance index $(r=0,58)$, that a high dominance of shade trees species could induce higher coffee productivity. Meanwhile the productivity of coffee in the private farms and the diversity of shade trees showed a weak correlation.

There was a fairly strong positive correlation between the productivity of coffee and some variables including the percentage of technical shade tree $(r=0.60)$ and the percentage of legume shade trees $(r=0.48)$ in CFP land, and the age of coffee farms $(r=0.52)$ in private land. However, the productivity of coffee was negatively correlated $(r=-0.53)$ with the percentage of timber shade tree in CFP land.

It is clear that age of coffee trees affects its productivity (Potvin et al. 2005) and the increasing age of the coffee will decrease the density of shade trees (Goodall et al. 2014) if not being replanted. Regarding to shade tree diversity, it has been reported that in Guatemala, by using four species of shade trees, the coffee production reached $925 \mathrm{~kg}$ ha-1, while in Peru that uses 17 species of shade trees, the coffee production was $386 \mathrm{~kg}$ ha-1 (Rice 2008). As the dominant shade tree, the genus Inga has been widely reported as legumes that enriches the soil due to the accumulation of biomass (Siles et al. 2010) and symbiosis with legume nodule bacteria. Therefore, the legume trees were widely used in the farm of organic coffee (Grossman et al. 2006). 
Table 2. Shade tree composition and coffee productivity

\begin{tabular}{|c|c|c|c|c|c|c|}
\hline $\begin{array}{l}\text { Land } \\
\text { tenure }\end{array}$ & Coffee age & $\begin{array}{c}\text { Technical shade } \\
\text { tree }\left(\% \mathbf{h a}^{-1}\right)\end{array}$ & $\begin{array}{c}\text { Wood trees } \\
\left(\% \mathbf{h a}^{-1}\right)\end{array}$ & $\begin{array}{l}\text { MPTS } \\
\left(\% \text { ha }^{-1}\right)\end{array}$ & $\begin{array}{c}\text { Ratio } \\
\text { shade/coffee } \\
\left(\% \text { ha }^{-1}\right) \\
\end{array}$ & $\begin{array}{c}\text { Coffee } \\
\text { productivity } \\
\left(00 \mathrm{~kg} \mathrm{ha}^{-1}\right) \\
\end{array}$ \\
\hline \multirow{2}{*}{ Private } & $<20$ year & 25.285 & 24.579 & 50.135 & 4.290 & 6.93 \\
\hline & $\geq 20$ year & 51.867 & 18.575 & 29.556 & 7.424 & 11.06 \\
\hline \multirow[t]{2}{*}{ CFP } & $<20$ year & 27.201 & 23.934 & 48.864 & 14.193 & 7.47 \\
\hline & $\geq 20$ year & 14.919 & 29.717 & 55.363 & 16.358 & 7.37 \\
\hline Average & & 32.73 & 23.50 & 43.76 & 10.86 & 8.52 \\
\hline
\end{tabular}

Table 3. Diversity index of coffee shade tree species

\begin{tabular}{lcccc}
\hline \multicolumn{1}{c}{ Land tenure } & $\begin{array}{c}\text { Coffee age } \\
\text { (year) }\end{array}$ & Shannon-Weiver Index $\left(\mathbf{H}^{\prime}\right)$ & $\begin{array}{c}\text { Simpson's dominance } \\
\text { Index }(\boldsymbol{\lambda})\end{array}$ & Species richness \\
\hline Private & $<20$ years & 1.3052 & 0.3184 & 4.6666 \\
& 20 years & 0.8229 & 0.4162 & 4.5454 \\
CFP & <20 years & 1.1547 & 0.4242 & 5.5555 \\
& 20 years & 1.4454 & 0.3510 & 7.7500 \\
\hline
\end{tabular}

Table 4. Correlation among variables on coffee productivity in private and CFP farms

\begin{tabular}{llll}
\hline & \multirow{2}{*}{ Variables } & \multicolumn{2}{c}{ Coffee productivity } \\
\cline { 3 - 4 } & & \multicolumn{1}{c}{ Private } & \multicolumn{1}{c}{ CFP } \\
\hline Shade & Shannon's index $\left(H^{\prime}\right)$ & -0.0177 & -0.5688 \\
tree & Dominance index $(\lambda)$ & 0.0721 & 0.5779 \\
& Species richness & 0.0455 & -0.3870 \\
& Abundance & 0.0873 & 0.2646 \\
& Technical shade tree $(\%)$ & 0.1661 & 0.5955 \\
& Wood tree $(\%)$ & 0.1628 & -0.5348 \\
& MPTS $(\%)$ & -0.3960 & -0.1479 \\
Coffee & Legume tree abundance $(\%)$ & 0.1306 & 0.4778 \\
tree & Density (tree ha-1) & 0.3483 & 0.2791 \\
& Age (year) & 0.5234 & -0.0898 \\
\hline
\end{tabular}

Table 5 presented the regression analysis of variables dominance index, the percentage of MPTS, type of land tenure, and the number of shade trees on the productivity of the coffee farms. Table 3-4 earlier showed that based on Shannon Index $\left(\mathrm{H}^{\prime}\right)$ and species richness, the highest diversity of shade trees was found in the CFP coffee farms aged $\geq 20$ years. Moreover, in the CFP coffee farms, dominance index $(\lambda)$ and the percentage of technical shade trees positively correlated to the coffee productivity. Likewise, Table 5 showed that the dominance index had a positive effect on productivity of coffee and the percentage MPTS had a negative effect. The type of land tenure (private or CFP) and the abundance of shade trees did not affect the productivity of coffee. In general, this indicates that the dominance of shade trees or technical shade trees such as G. sepium, E. subumbrans, L. leucocephala, D. latifolia, and $P$. falcataria had positive effect on the productivity of coffee. On the contrary, the higher the percentage of MPTS resulted in the lower the coffee productivity.

In private coffee farms the average density of shade trees was 135 trees $\mathrm{ha}^{-1}$, and in the CFP coffee farms was 310 trees ha ${ }^{-1}$. That could be included as medium density of shade trees based on farmers' norm on new planting of coffee in farms in Sumberjaya Sub-district (density $<100$ trees $=$ low, $100-400=$ medium, $>400=$ high). Rice (2008) reported that dominant shade of legume tree had a positive influence on coffee productivity. However, Ebisa (2014) reported that both legume and non-legume species of shade trees had less significant effect on the productivity of coffee. Shade trees could decrease or raise the productivity of coffee or could have no effect (Shalene et al. 2014)

Table 5. Regression analysis of some variables on coffee productivity

\begin{tabular}{lllll}
\hline Variable & Coefficient & Std. Error & t calc. & Significance \\
\hline Constantan & 0.8584 & 0.2331 & 3.68254 & 0.00094 \\
Dominance index $(\lambda)$ & 0.8104 & 0.4711 & 1.72037 & $0.09602^{*}$ \\
\% MPTS & -0.6018 & 0.3267 & -1.84184 & $0.07575^{*}$ \\
Land tenure (private vs CFP) & -0.2258 & 0.2027 & -1.11397 & 0.27444 \\
Shade trees abundance & 0.0003 & 0.0007 & 0.34125 & 0.73538 \\
$\mathrm{R}^{2}$ & 0.263 & & & \\
F calc. & 2.581 & & & \\
Significance of F calc. & 0.058 & & & \\
\hline
\end{tabular}

Note: * Significant at level $\alpha 10 \%$ 
depending on the species of shade trees (Long et al. 2015), the density and diversity of shade trees (Schmitt et al. 2009), shade tree structures (Hernandez-Martinez et al. 2009), fertilization, variety and age of coffee (Potvin et al. 2005). The characteristics of trees that serve optimal shade, fertilize the soil, and provide additional products would affect the farmers in selecting the species of shade trees to plant in coffee farms (Kalanzi and Nansereko 2014).

In conclusion, shade trees found in coffee farms of Sumberjaya were 36 species, 10 species (28\%) of which were legume trees. Technical shade trees that have high importance value were $G$. sepium and E. subumbrans. MPTS widely planted were $D$. zibethinus and $P$. speciosa. The wood trees with a high importance value in the CFP coffee farms were $S$. javanica and $M$. champaca while in private coffee farms were $M$. eminii and Litsea sp. Based on Shannon's index (H') and Simpson's dominance index $(\lambda)$, a high diversity of shade trees species was found in CFP coffee farms at age $\geq 20$ years. Shade trees with high dominance index had a positive effect on productivity of coffee, and the percentage of MPTS had a negative effect. Whereas, the type of land tenure (private or CFP) and the abundance of shade trees did not affect the productivity of coffee.

\section{ACKNOWLEDGEMENTS}

The authors would like to thank the Directorate for Research and Community Service, Directorate General for Higher Education for funding through Fundamental Research Grant in 2015.

\section{REFERENCES}

Ambinakudige S, Sathish BN. 2008. Comparing tree diversity and composition in coffee farms and sacred forests in the Western Ghats of India. Biodivers Conserv. DOI 10.1007/s10531-008-9502-5.

Bote AD, Struik PC. 2011. Effects of shade on growth, production and quality of coffee (Coffea arabica) in Ethiopia. J Hortic For 3: 336341 .

Capitan GC, Avila-Bello CH, Lopez-Mata L, Gonzales FL. 2014. Structure and tree diversity in traditional Popoluca coffee agroecosystem in the Los Tuxtlas Biosphere Reserve Mexico. Interciencia 39: 608-619.

Cerdan, CR, Rebolledo MC, Soto G, Rapidel B, Sinclair FL. 2012. Local knowledge of impacts of tree cover on ecosystem services in smallholder coffee production systems. Agric Sys 110: 119-130.

Ebisa L. 2014. Effect of dominant shade trees on coffee production in Manasibu District, West Oromia, Ethiopia. Sci Technol Art Res J 3: 18-22.

Evizal R, Tohari, Prijambada ID, Widada J, Widianto D. 2009. Biomass production of shade-grown coffee agroecosystems. Proceeding International Seminar on Sustainable Biomass Production and Utilization Challenges and Oppurtunities (ISOMASS). Bandar Lampung, 3-4 August 2009.

Evizal R, Tohari, Prijambada ID, Widada J, Widianto D. 2012. Soil bacterial diversity and productivity of coffee-shade tree agroecosystems. J Trop Soils 17: 181-187

Geta T, Nigatu L, Animut G. 2014. Ecological and socio-economic importance of indigenous multipurpose fodder trees in three Districts of Wolayta Zone, Southern Ethiopia. J Biodivers Endanger Species 2 (4). http: //dx.doi.org/10.4172/2332-2543.1000136.
Goodall KE, Bacon CM, Mendez VE. 2014. Shade tree diversity, carbon sequestration, and epiphyte presence in coffee agroecosystems: A decade of smallholder management in San Ramon, Nicaragua. Agric Ecosyst Environ 199: 200-206.

Grossman JM, Sheaffer C, Wyse D, Bucciarelli B, Vance C, Graham PH. 2006. An assessment of nodulation and nitrogen fixation in inoculated Inga oerstediana, a nitrogen-fixing tree shading organically grown coffee in Chiapas, Mexico. Soil Biol Biochem 38: 769-784.

Hernandez-Martınez G, Manson RH, Hernandez AC. 2009. Quantitative classification of coffee agroecosystems spanning a range of production intensities in central Veracruz, Mexico. Agric Ecosyst Environ 134: 89-98.

Kalanzi F, Nansereko S. 2014. Exploration of farmers' tree species selection for coffee agroforestry in Bukomansimbi district of Uganda. Int J Res Land-use Sustain 1: 9-17.

Kufa T, Burkhardt MJ. 2011. Plant composition and growth of wild Coffea arabica: Implications for management and conservation of natural forest resources. Int J Biodivers Conserv 3: 131-141.

Lin BB, Richards PL. 2007. Soil random roughness and depression storage on coffee farms of varying shade levels. Agric Water Manag 92: 194-204.

Long NV, Ngoci NQ, Dung NN, Kristiansen P, Yunusa I, Fyfe C. 2015. The effects of shade tree types on light variation and Robusta coffee production. Engineering 7: 742-753.

Lopez-Gomez AM, Williams-Linera G, Manson RH. 2008. Tree species diversity and vegetation structure in shade coffee farms in Vercruz, Mexico. Agric Ecosyst Environ 124: 160-172.

Lopez-Rodriguez G, Sotomayur-Ramirez D, Amador JA, Schroder ED. 2015. Contribution of nitrogen from litter and soil mineralization to shade and sun coffee (Coffea arabica L.) agroecosystems. Trop Ecol 56: 155-167.

Mamani-Pati F, Clay DE, Clay SA, Smeltekop H, Yujra-Callata MA. 2012. The influence of strata on the nutrient recycling within a tropical certified organic coffee production system. ISRN Agron 2012: 1-8. DOI: 10.5402/2012/389290.

Maridi, Agustina P, Saputra A. 2014. Vegetation analysis of Samin watershed, Central Java as water and soil conservation efforts. Biodiversitas 15: 215-223.

Mbow C, Smith P, Skole D, Duguma L, Bustamante M. 2014. Achieving mitigation and adaptation to climate change through sustainable agroforestry practices in Africa. Curr Opin Environ Sustain 6: 8-14.

Moonen A, Barberi P. 2008. Functional biodiversity: An agroecosystem approach. Agric Ecosyst Environ 127: 7-21.

Morris EK, Caruso T, Buscot F, Fischer M, Hancock C , Maier TS, Meiners T, Muller C, Obermaier E, Prati D, Socher SA, Sonnemann I, Waschke N, Wubet T, Wurst S, Rillig MC. 2014. Choosing and using diversity indices: insights for ecological applications from the German Biodiversity Exploratories. Ecol Evol 4: 3514- 3524.

Pasha R, Asmawan T, Leimona B, Setiawan E, Wijaya CI. 2012. Commoditized or co-invested environmental services? Rewards for environmental services scheme: River Care program, Way Besai watershed, Lampung, Indonesia. Working Paper No. 148. Bogor, Indonesia: World Agroforestry Centre (ICRAF) Southeast Asia Regional Program. DOI: 10.5716/ WP12051.PDF.

Pender J, Suyanto, Kerr J, Kato E. 2008. Impacts of the Social Forestry Program in the Sumberjaya Watershed, West Lampung District of Sumatra, Indonesia. International Food Policy Research Institute. Washington DC.

Philpott SM, Bichier P, Rice RA, Greenberg R. 2008. Biodiversity conservation, yield, and alternative products in coffee agroecosystems in Sumatra, Indonesia. Biodivers Conserv 17: 1805-1820.

Potvin C, Owen CT, Melzi S, Beaucage P. 2005. Biodiversity and Modernization in Four Coffee-producing Villages of Mexico. Ecology and Society 10. www.ecologyandsociety.org/vol10/iss1 /art18/

Rice RA. 2008. Agricultural intensification within agroforestry: The case of coffee and wood products. Agric Ecosyst Environ 128: 212-218.

Schmitt CB, Senbeta F, Denich M, Preisinger H, Boehmer HJ. 2009. Wild coffee management and plant diversity in the montane rainforest of southwestern Ethiopia. Afr J Ecol 48: 78-86.

Shalene JHA, Bacon CM, Philpott SM, Mendez VE, Laderach P, Rice RA. 2014. Shade coffee: Update on a disappearing refuge for biodiversity. Bioscience 64: 416-428. 
Siles P, Harmand J, Vaast P. 2010. Effects of Inga densiflora on the microclimate of coffee (Coffea arabica L.) and overall biomass unde optimal growing conditions in Costa Rica. Agrofor Syst 78: 269-286.

Soto-Pinto L, Villalvazo-Lopez V, Jimenez-Ferrer G, Ramirez-Marcial N, Montoya G, Sinclair FL. 2007. The role of local knowledge in determining shade composition of multistrata coffee systems in Chiapas, Mexico. Biodivers Conserv 16: 419-436.

Sumantra IK, Ashari A, Wardiyati T, Suryanto A. 2012. Diversity of shade trees and their influence on the microclimate of agro-ecosystem and fruit production of Gulapasir Salak (Salacca zalacca var. Amboinensis) fruit. Int J Basic Appl Sci 12: 214-221.

Tadesse G, Zavaleta E, Shennan C. 2014. Coffee landscapes as refugia for native woody biodiversity as forest loss continues in southwest Ethiopia. Biol Conserv 169: 384-391.
Tscharntke T, Clough Y, Bhagwat SA, Buchori D, Faust H, Hertel D, Holscher D, Juhrbandt J, Kessler M, Perfecto I, Scherber C, Schroth G, Veldkamp E, Wanger TC. 2011. Multifunctional shade-tree management in tropical agroforestry landscapes - a review. J Appl Ecol 48: 619-629.

Valencia V, West P, Sterling EJ, Garcia-Barrios L, Naeem S. 2015. The use of farmers' knowledge in coffee agroforestry management: implications for the conservation of tree biodiversity. Ecosphere 6 (7): 122. http: //dx.doi.org/10.1890/ES14-00428.1

Verbist B, Putra AED, Budidarsono S. 2005. Factors driving land use change: Effects on watershed functions in a coffee agroforestry system in Lampung, Sumatra. Agric Syst 85: 254-270. 